\title{
Predicting User Satisfaction Using an Extended EUCS Model (The Case of Customer Application System in Telkom)
}

\author{
$1^{\text {st }}$ Muhammad Qomarul Huda ${ }^{1}, 2^{\text {nd }}$ Evy Nurmiati ${ }^{1}, 3^{\text {rd }}$ Nur Winda Sari ${ }^{1}$ \\ \{mqomarul@uinjkt.ac.id ${ }^{1}$, evy_nurmiati@uinjkt.ac.id ${ }^{1}$, nurwindasari14@mhs.uinjkt.ac.id ${ }^{1}$ \} \\ UIN Syarif Hidayatullah, Department of Information Systems, Jakarta, Indonesia ${ }^{1}$
}

\begin{abstract}
The user satisfaction construct is an important aspect of the Information Systems field either both research and practice. Additionally, the manner in which to evaluate the user satisfaction of an information system has changed over time as the context and purpose has evolved. Therefore, the various of evaluation model is essential to understand the trends in user satisfaction measurement and what they mean for the future.Measuring user satisfaction in IS research indicated the multidimension approach. This study proposed an extendedEnd-User Computing Satisfaction (EUCS) model that used to predict the user satisfaction in the context of internet service company in Indonesia known as Telkom. Two variables such as security and response speed were incorporated in the inventiveEUCS variable modelbased on past literature. This research employ a quantitative approach with the selected customers were sampled usingsurvey method. The answer from the respondents then analyzed using the IBMStatisticalPackage for the Social Sciences (SPSS) software version 20. As a result, the level of user satisfaction of the current system is at a fairly satisfied level.
\end{abstract}

Keywords: User satisfaction, Telkom, EUCS, PLS-SEM.

\section{Introduction}

Effective management of information systems within a company is very important as it can be an underpinning to gain competitive advantage. Therefore, many companies begin to develop and pay special attention to the information system as a source that facilitates the effective collection and use of information. In actual implementation, IT innovation is much more difficult to control because it involves complex interaction between human, technology and environment. Often there are barriers in using new technology and in many situations and organizations have to face the failure of IT implementation [1].

One of the IT application system employed by Telkom's company that used to maintain close relationship with customer was Indihome. During providing services to the customers there were sometimes complaints arise from potential customers. The kind of complaints such as related to the accuracy of the system, where sometimes the billing of payment is not in accordance with the system. The other aspect of user satisfaction related to the security and speed of access is also questioned by users of the system. Given the large number of information systems and users involved, it is necessary to consider a scoring system that measures the extent of the interactions. The interactions referred to here may represent by how 
much users' benefit can be obtained or the extent to which level of user satisfaction to the enterprise information systems. However, based on the internal information, this system has never been evaluated related to user satisfaction, especially customer parts system. So, there is no study that describes how much user satisfaction in using the system and what factors that affect user satisfaction with the system.

In recent years, researchers have investigated a variety of approaches to measure the user satisfaction but, the study not focus on security aspect and speed of response of the application system. Another thing is, a little progress has been made in the field of measurement user satisfaction in this company. Based on the above background then the research has been undertaken for predicting of the User Satisfaction. This study employ an extended End User Computing Satisfaction Model that cover 8 variables, those are: content, accuracy, format, timeliness, ease of use, security, access speed, and user satisfaction itself.. The purpose of this research is to predict the level of user satisfaction for using the application of My Indihome.

\section{Literatur Review}

\subsection{Measurement of System User Satisfaction}

Measurement of the user satisfaction related to the user behavior in terms of their response to several factors related to the delivery of information about products and services [2].The mission of developing an Information System asthe effective use and impact of IT in organizations and society[15].Based on this view of information systems, predicting user satisfaction of an IT application is an important aspect of the field of information systems both in research and practice.

\subsection{Information Systems CRM MyIndihome}

Telkom is one of the main Indonesian companies in terms of market capitalization. It is the holding company of the Telkom Group, which is engaged in a wide range of businesses including telecommunication and multimedia. One of Telkom's products on internet services called by Indihome. The IT application that has been implemented for customer relationship management called by My Indihome. Using this application through subscribing requirement, the registered customer may access the system to request any services provided by Telkom, such as activation Video Streaming, registration various additional features, reporting IndiHome service interruption, checking the billing, checking point reward, usage info, and providing free music as well as other interesting services. My Indihomehas a tagline with a theme that is easy, comfortable, can be done anywhere and anytime. The registered user and customer can access easily the application at https://my.indihome.co.id.

\section{End User Computing Satisfaction (eucs)}

The original model that was underpinning of the study is End User Computing Satisfaction model developed by Doll and Torkzadeh (1988) consisting of 5 variables: Content, Format, Accuracy, Timeliness and Ease of Use [3]. In addition, there are two additional variables: security and speed for predicting user satisfaction adopted from previous research model [4]. Given the need for information security in a system, in the sense of 
security required at the time the information is transmitted, in order to maintain the authenticity of the data when transmitted through electronic transmission, the researcher uses the theory / concept of security [5], which states the higher the quality of information, information, and ease of use of information systems, the higher the level of user satisfaction. Researchers also use the theory or concept of speed [6] because the speed of media response such as access speed and loading speed in information technology can provide its own convenience for users, so users can get satisfaction in using information technology services.

This study uses 8 variables in the research model that includes Content, Accuracy, Format, Ease of Use, Timeliness, Security, Speed of Response and End-User Satisfaction.

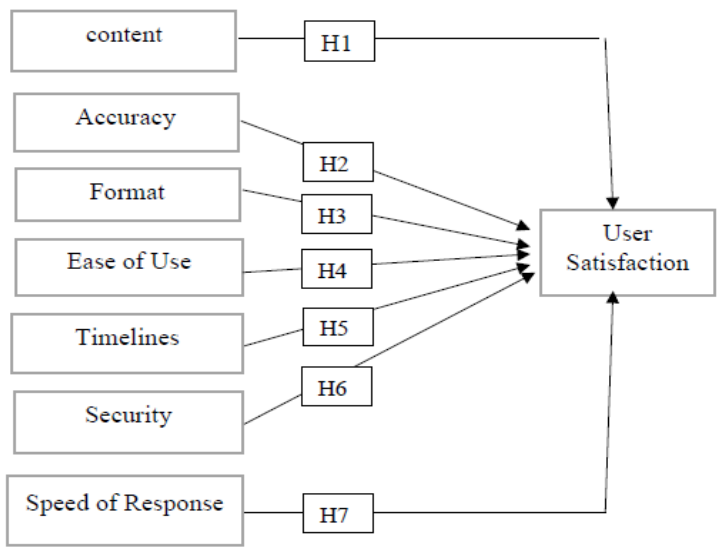

Figure 1. User Statisfaction

\section{Research Method}

This research itself is generally done with quantitative approach according to its purpose that is predicting end user satisfaction from the side of contents, accuracy, ease, shape, timeliness, security and speed of information system. Data collection used in this research is in the form of interview, literature study and survey by distributing questionnaires.

The Simple Random Sampling method was employed in this study without regard to the strata of current population [7], by determining the number of samples using the PLS-SEM techniques [8].

\subsection{Data Collection}

In the process of data collection, this research is done by distributing the questionnaire indirectly, that is by requesting assistance to supervisorof the branch of Plasa Telkom KebonSirih. The respondents have been accessed through their email address to respond the questionnaires using google forms feature. The researcher realized that the spreading of the questionnaire through online system will reduce the interesting of respondents in filling the questionnaire. To appreciate the respondent that have been involved in this survey, the Plasa Telkom will give discounted 1\% for once billing payment their Indihomes' subscriber. 


\subsection{Population and Sample}

In this study the target population is the user MyIndihome in Plasa Telkom KebunSirihwho play a direct role in using the system MyIndihome, where Plasa Telkom KebunSirih is one of the Plasa Telkom which has the most customers from local and foreign customers. Based on the report dated January 31, 2018, the number of MyIndihome users obtained from Supervisor of Plasa Telkom KebunSirih is 5,340 people. To determine the number of samples is done based on the criteria of the number of samples with the approach of PLS SEM, which is at least 10 times the number of paths in the research model [9], where in this study there are seven hypotheses so that the minimum sample is 70 .

\subsection{Instruments}

Instrument of this research using Questionnaire which consist of explanation of research questions. The questionnaire consisted of five questions about the respondent's profile, 4 questions about using MyIndihome, and 25 test questions that had been adapted to the variables that existed in the expanded EUCS model. To ensure the validity and reliability of this questionnaire, researchers adopted a number of indicator items from a number of previous related studies [10] [11] [12] [13].

\section{The Result}

This section presents the findings that have been done by spreading the questionnaire indirectly (online).

\subsection{Gender}

Table 1. Shows the Characteristics of Respondents by Gender

\begin{tabular}{|c|c|c|c|}
\hline \multirow{2}{*}{ NO } & \multicolumn{3}{|c|}{ Frequency of Answer Gender } \\
\cline { 2 - 4 } & Characteristics & Frequency & Presentation \\
\hline 1. & Female & 87 & $52 \%$ \\
\hline 2. & Male & 80 & $48 \%$ \\
\hline
\end{tabular}

Female respondents that is $52 \%$ or as many as 87 people have a higher frequency than male respondents who have $48 \%$ or as many as 80 people, this is because researchers provide Indihome payment discounts for those who fill the questionnaire, while the interest of women will be discounts offered in more questionnaires attractive to women than men.

5.2 Age

Table 2. Shows The Characteristics of Respondents by Age

\begin{tabular}{|l|c|c|c|}
\hline \multirow{2}{*}{ NO } & \multicolumn{3}{|c|}{ Frequency of Answer Age } \\
\cline { 2 - 4 } & Characteristics & Frequency & Presentation \\
\hline 1. & $12-20$ Year & 25 & $15 \%$ \\
\hline 2. & $21-29$ Year & 57 & $34 \%$ \\
\hline
\end{tabular}




\begin{tabular}{|l|c|c|c|}
\hline \multirow{2}{*}{ NO } & \multicolumn{3}{|c|}{ Frequency of Answer Age } \\
\cline { 2 - 4 } & Characteristics & Frequency & Presentation \\
\hline & $30-38$ Year & 59 & $35 \%$ \\
\hline & $>38$ Year & 26 & $16 \%$ \\
\hline
\end{tabular}

Respondents who have the highest frequency of respondents with age between 30-38 years $35 \%$ or as many as 59 people and the lowest respondent is the respondent age between $12-20$ years that is equal to $15 \%$ or as many as 25 people. This is because the majority of MyIndihome users are workers with a population of 5,340 who are in the productive age range of the age of 30-38 years.

\subsection{Education}

Table 3. Shows The Characteristics of Respondents Based on Latest Education

\begin{tabular}{|l|c|c|c|}
\hline \multirow{2}{*}{ NO } & \multicolumn{3}{|c|}{ Frequency of AnswerEducation } \\
\cline { 2 - 4 } & Characteristics & Frequency & Presentation \\
\hline \multirow{2}{*}{} & SD & 22 & $13 \%$ \\
\hline & SMP & 29 & $17 \%$ \\
\hline & SMA & 40 & $24 \%$ \\
\hline & $\begin{array}{c}\text { Akademik/Perguruan } \\
\text { Tinggi }\end{array}$ & 76 & $46 \%$ \\
\hline
\end{tabular}

Respondents who have the highest frequency of respondents with the last education Academic / Higher Education of $46 \%$ or as many as 76 people and the lowest respondent is the respondent with the last elementary education that is $13 \%$ or as many as 22 people. This result is because the user MyIndihome better understand will use system which educated Academic / Higher Education, while for education of SD, user more difficult to understand or reluctant to use system. Students are generally self-sufficient and more accustomed to Internet-based and more educated technology services than casual users [14].

\subsection{Length of Use}

Table 4. Shows Respondent Characteristics Based on Length of Use

\begin{tabular}{|c|c|c|c|}
\hline \multirow{2}{*}{ NO } & \multicolumn{3}{|c|}{ Frequency of Answer Lengh of Use } \\
\cline { 2 - 4 } & Characteristics & Frequency & Presentation \\
\hline & $<1$ Year & 57 & $34 \%$ \\
\hline & $1-2$ Year & 52 & $31 \%$ \\
\hline & $3-4$ Year & 16 & $10 \%$ \\
\hline
\end{tabular}

Respondents with the old system using $<1$ year of $34 \%$ or as many as 57 people and the lowest respondents are respondents with a long time using the system between 3-4 years of $10 \%$ or as many as 16 people, this is causing new Indihome customers after 35\% in 2017. 


\subsection{Usage Requirement.}

Table 5. Shows Respondent Characteristics Based on Usage Requirement

\begin{tabular}{|r|c|c|c|}
\hline \multirow{2}{*}{ NO } & \multicolumn{3}{|c|}{ Frequency of Answer Usage Requirement } \\
\cline { 2 - 4 } & Characteristics & Frequency & Presentation \\
\hline 1 & Personal & 92 & $55 \%$ \\
\hline 2 & Education & 29 & $17 \%$ \\
\hline 3 & Business & 46 & $28 \%$ \\
\hline
\end{tabular}

Respondents who have the highest frequency of respondents with the needs of the use of the system for personal that is equal to $55 \%$ or as many as 92 people and the lowest respondent is the respondent with the use of the system for education that is equal to $17 \%$ or as many as 29 people. When viewed from job demographics, private employees and students have the highest percentage, this leads to the need to use the system itself more for personal.

\subsection{Role of the System.}

Table 6. Shows The Characteristics Respondents Based on The Role of The System

\begin{tabular}{|r|c|c|c|}
\hline \multirow{2}{*}{ NO } & \multicolumn{3}{|c|}{ Frequency of Answer Role of the System } \\
\cline { 2 - 4 } & Characteristics & Frequency & Presentation \\
\hline 1. & Very Helpfull & 5 & $3 \%$ \\
\hline 2. & Helpfull & 114 & $68 \%$ \\
\hline 3. & QuiteHelpfull & 33 & $20 \%$ \\
\hline 4. & Less Helpful & 14 & $8 \%$ \\
\hline 5. & Not Helpfull & 1 & $1 \%$ \\
\hline
\end{tabular}

Respondents who have the highest frequency of respondents with the level of application system that is considered to help that is equal to $68 \%$ or as many as 114 people and the lowest respondent is the respondent with the level of system implementation is considered not helpful that is equal to $1 \%$ or as much as 1 person.

\subsection{User System Satisfaction Status}

Table 7. Shows The Characteristics of Respondents by Work

\begin{tabular}{|l|c|c|c|}
\hline \multirow{2}{*}{ NO } & \multicolumn{3}{|c|}{ Frequency of Answeruser System Satisfaction Status } \\
\cline { 2 - 4 } & Characteristics & Frequency & Presentation \\
\hline 1. & Very Satisfied & 14 & $8 \%$ \\
\hline 2. & Satisfied & 90 & $54 \%$ \\
\hline 3. & QuiteSatisfied & 52 & $31 \%$ \\
\hline 4. & LessSatisfied & 10 & $6 \%$ \\
\hline 5. & NotSatisfied & 1 & $1 \%$ \\
\hline
\end{tabular}


Respondents who have the highest frequency of respondents with satisfaction level of satisfied system users that is equal to $54 \%$ or as many as 90 people and the lowest respondent is the respondent with the satisfaction level of system users who are not satisfied that is equal to $1 \%$ or as much as 1 person.

\section{Conclusion}

From the results of demographic data processing is known that as many as $54 \%$ of respondents feel satisfied when using MyIndihome, this is because respondents feel helped by the system in the completion of tasks / their work, in addition reinforced by the number of users who are in vulnerable productive age of 30-38 and the last educated academic / college, so users will feel more benefit and usefulness of the system.

While on the other hand there are $6 \%$ of respondents feel less satisfied and $1 \%$ of respondents feel not satisfied, this is because respondents feel the system is less helpful in completing their task / job. efforts to be made by Plasa Telkom to improve user satisfaction is to improve or develop the system so that the presentation of information produced more accurate, one of them by adjusting the output screen results with what the user ordered, so the system produces reliable and reliable information by users.

Acknowledgements. This paper in conjuction with the 1st International Conference On Islam, Science, And Technology (ICONIST) 2018, Malang, East Java.

\section{References}

[1] Huda, M. Q., \&Hussin, H. (2014). A Model for Evaluating IT Innovation Implementation Effectiveness in Higher Educational Institutions in Indonesia.

[2] Prihastono, E. (2011). Pengukuran Tingkat KepuasanPengguna Sistem Informasi Dengan Model Matematis Non Linear. Jurnal Ilmiah Dinamika Teknik.

[3] Doll, W. J., \&Torkzadeh, G. (1988). The Measurement of End-User Computing Satisfaction. MIS quarterly.

[4] Waluyo, Slamet B. (2010) Pengaruh Instrumen EUCS, Faktor Keamanan dan Privasi serta Kecepatan Respon Media Terhadap Kepuasan Pengguna E-learning. STIE Perbanas. Surabaya

[5] Liviana, D., \& Dahlia, B. Analisis Pengaruh Kualitas Informasi, Keamanan Informasidan Kemudahan Penggunaan Sistem Informasi Terhadap Kepuasan Pengguna (2014).

[6] Nawangsari, S., Mayang, R., \&Prasetyo, E. Analisis Diskritif Kepuasan Masyarakat Pengguna Terhadap Layanan Situs Web Bank X (2008).

[7] Sugiyono, Metode Penelitian Kombinasi (Mixed Methods), Bandung: Penerbit Alfabeta. Bandung (2011).

[8] Yamin, S. \& Kurniawan, H. Generasi Baru Mengolah Data Penelitiandengan Partial Least Square Path Modeling: Aplikasidengan Software XLSTAT, SmartPLS, dan Visual PLS. Edisi 1. Salemba Infotek. Jakarta (2011).

[9] Hair, J. F., Sarstedt, M., Ringle, C. M., \& Mena, J. A. An assessment of the use of partial least squares structural equation modeling in marketing research. Journal of The Academy of Marketing Science, Vol. 40 No. 3 (2012).

[10] Rasman, Indra Yoel K. Gambaran Hubungan Unsur-Unsur End-User Computing Satisfaction terhadap Kepuasan Pengguna Sistem Informasi Rumah Sakit di RumahSakitUmum Daerah Kota Depok Tahun 2012.Skripsi. Universitas Indonesia. Depok (2012). 
[11] Bayu, Arya Setiawan Evaluasi kepuasan pengguna aplikasi Surat Keterangan Tinggal Sementara online dengan menggunakan End User Computing Satisfaction pada Dinas Kependudukan dan Catatan Sipil (Dispendukcapil) Kota Surabaya (2016).

[12] Santoso, Wahyu. Analisis Faktor Atas Kepuasan Mahasiswa S1 Akuntansi Dalam Mengakses Simas Di STIE Perbanas Surabaya (2014).

[13] Chin, W. W., \& Lee, M. K. (2000, December). A proposed model and measurement instrument for the Formation of IS satisfaction: the case of end-user computing satisfaction. In Proceedings of the twenty first international conference on InFormation systems, Association for InFormation Systems.

[14] Susanto, A., Lee, H., Zo, H., \&Ciganek, A. P. Factors Affecting Internet Banking Success: A comparative Investigation Between Indonesia and South Korea. Journal of Global InFormation Management (JGIM) (2013).

[15] W. H. DeLone and E. R. McLean, "Information systems success measurement," Found. Trends ${ }^{\circledR}$ Inf. Syst., vol. 2, no. 1, pp. 1-116, 2016. 